\title{
Variability, Heritability and Genetic Advance for Quantitative Characters in Rice Fallow Blackgram [Vigna mungo (L.) Hepper]
}

\author{
Hari Ram Kumar Bandi ${ }^{1 *}$, K. Nagendra Rao ${ }^{1}$, K. Vamsi Krishna ${ }^{2}$ and K. Srinivasulu ${ }^{3}$ \\ ${ }^{1}$ Department of Genetics \& Plant Breeding, ANGRAU-Guntur-522509, India \\ ${ }^{2}$ Department of Genetics \& Plant Breeding, Agricultural College Bapatla-Guntur, India \\ ${ }^{3}$ Department of Agronomy, ANGRAU-Guntur-522509, India
}

*Corresponding author

\begin{abstract}
A B S T R A C T
\end{abstract}
Keywords

Variability,

Heritability, Genetic

advance, Blackgram

and quantitative traits

Article Info

Accepted:

04 January 2018

Available Online:

10 February 2018
An investigation was carried out with thirty six blackgram genotypes in rice fallow situation, to assess the variability, heritability and genetic advance for yield and yield attributing characters. The results revealed that high PCV and GCV for number of clusters per plant and high PCV coupled with moderate GCV for number of branches per plant and grain yield per plant exhibiting wider range of variability. Whereas, number of pods per plant and 100 seed weight recorded moderate variability. High heritability coupled with high genetic advance as per cent of mean was observed for number of branches per plant, number of clusters per plant, number of pods per plant, 100 seed weight and grain yield per plant indicating that the heritability was due to additive gene effects which may be exploited through breeding methods involving simple selection like pedigree method, mass selection, ear-to-row methods for the improvement of these traits.

\section{Introduction}

Blackgram [Vigna mungo (L.) Hepper], was popularly known as Urdbean, urid or mash. It was domesticated from $V$. mungo var. silvestris (Lukoki et al., 1980). Blackgram is one of the most ancient and important legume crop of India, the primary centre of origin of Urdbean and about $70 \%$ of the world's Urdbean production and contributes $70 \%$ of world's total production (Priyanka et al., 2016). Urdbean consists of good nutritional values of high seed protein (25-26\%), carbohydrates $(60 \%)$, fat $(1.5 \%)$, minerals, amino acids and vitamins. Hence, it is usually known as "poor man's meat" particularly in the vegetarian population of the Indian subcontinent (Chubatemsu and Malini, 2017). It has the ability to restore the soil fertility through symbiotic nitrogen fixation and suitable for various crop rotation practices and well suited in both dry and irrigated conditions. This is one of the most important short duration legume crop utilized in the food, fodder, soil conservation, integrated farming systems, reclaiming of degraded pastures and symbiotic nitrogen fixation. It is 
essential to understand the genetic architecture and nature of gene action governing yield and its component traits for increasing the yield per unit area. Yield is the resultant product of various morphological, physiological and biological components. The yield of pulses in general and black gram in particular remains at low level and there is a need for improvement.

The success of any breeding programme depends upon the quantum of genetic variability present in the population. Wider range of genetic variability helps in selecting desired genotypes. Variability is one such estimate provides a clear-cut idea about a particular traits on which greater emphasize should be given during selection. In addition to the genetic variability, knowledge on heritability and genetic advance helps the breeder to employ the suitable breeding strategy. Heritability of a character provides an idea of the extent of genetic control for the expression of a particular character (Priyanka et al., 2016). Moreover, heritability serves as a guide to the reliability of phenotypic variability in the selection program and hence determines its success. Johnson et al., 1995, reported that heritability estimates along with genetic advance are more reliable than heritability alone to the predict effect of selecting the best individuals. Genetic advance indicates the magnitude of the expected genetic gain from one cycle of selection. In this regards, the present investigation was undertaken to evaluate variability, heritability and genetic advance of 10 quantitative characters in 36 black gram genotypes to provide necessary information that could be useful to improve yield traits.

\section{Materials and Methods}

Thirty six blackgram (Vigna mungo (L.) Hepper) genotypes of diverse origin were raised in rice fallow situation in a Randomized
Block Design in three replications, each of 4 rows of 4 meters length with spacing of row to row $30 \mathrm{~cm}$ and plant to plant of $10 \mathrm{~cm}$ at Agricultural Research Station, Ghantasala, Krishna District, during Rabi, 2016-17. All the recommended package of practices was followed to raise a good crop.

Observations were recorded for 10 quantitative characters viz., days to $50 \%$ flowering, days to maturity, plant height $(\mathrm{cm})$, number of branches per plant, number of clusters per plant, number of pods per plant, pod length $(\mathrm{cm})$, number of seeds per pod, 100 seed weight $(\mathrm{g})$ and grain yield per plant $(\mathrm{g})$. Data was recorded from five randomly selected plants of each genotype per replication and the average was taken for analysis. Standard statistical procedures were used for the analysis of genetic variability estimates of quantitative traits such as PCV, GCV, heritability and genetic advance were worked out as per Johnson et al., (1955) and Hanson (1963).

\section{Results and Discussion}

The mean sum of squares due to genotypes were highly significant at $1 \%$ level of significance for days to $50 \%$ flowering, days to maturity, plant height $(\mathrm{cm})$, number of branches per plant, number of clusters per plant, number of pods per plant, pod length (cm), number of seeds per pod, 100 seed weight $(\mathrm{g})$ and grain yield per plant $(\mathrm{g})$. This indicated the existence of considerable variability for all characters studied among the genotypes.

Hence, it offers a better scope for further improvement of breeding material by the selection of promising genotypes in Blackgram breeding programme. The mean sum of squares of various characters is presented in Table 1. 
Table.1 Mean performance of $\mathbf{3 6}$ genotypes of rice fallow blackgram [Vigna mungo (L.) Hepper] for yield and yield component characters

\begin{tabular}{|c|c|c|c|c|c|c|c|c|c|c|c|}
\hline S. No & Genotypes & $\begin{array}{c}\text { Days to } 50 \% \\
\text { flowering }\end{array}$ & $\begin{array}{c}\text { Days to } \\
\text { maturity }\end{array}$ & $\begin{array}{c}\text { Plant } \\
\text { height }(\mathrm{cm})\end{array}$ & $\begin{array}{l}\text { No. of branches } \\
\text { per plant }\end{array}$ & $\begin{array}{c}\text { No. of clusters } \\
\text { per plant }\end{array}$ & $\begin{array}{c}\text { No. of pods } \\
\text { per plant }\end{array}$ & $\begin{array}{l}\text { Pod length } \\
\text { (cm) }\end{array}$ & $\begin{array}{c}\text { No. of seed } \\
\text { per pod }\end{array}$ & $\begin{array}{c}100 \text { Seed } \\
\text { weight }(g)\end{array}$ & $\begin{array}{l}\text { Grain yield per } \\
\text { plant (gm) }\end{array}$ \\
\hline 1 & LBG 623 & 46.50 & 77.50 & 21.96 & 2.50 & 4.50 & 26.50 & 3.04 & 6.00 & 4.61 & 6.42 \\
\hline 2 & VBG 4-008 & 45.00 & 75.50 & 18.48 & 2.50 & 5.50 & 36.00 & 4.02 & 7.00 & 4.41 & 9.09 \\
\hline 3 & VBG 4-14 & 45.00 & 76.50 & 21.07 & 3.00 & 7.00 & 33.00 & 4.05 & 6.50 & 4.35 & 7.58 \\
\hline 4 & Uttara & 40.00 & 69.50 & 19.98 & 1.50 & 4.50 & 30.50 & 4.03 & 6.00 & 3.60 & 6.52 \\
\hline 5 & LBG 17 & 46.00 & 75.50 & 19.15 & 3.00 & 3.50 & 21.50 & 4.06 & 5.50 & 4.40 & 4.95 \\
\hline 6 & TGBG 40 & 46.50 & 79.50 & 23.25 & 2.50 & 4.50 & 27.00 & 4.05 & 5.50 & 4.55 & 6.46 \\
\hline 7 & LBG 402 & 48.00 & 80.00 & 21.87 & 3.00 & 3.50 & 23.50 & 4.07 & 6.50 & 4.65 & 6.64 \\
\hline 8 & KKB 05011 & 48.50 & 79.00 & 24.27 & 3.00 & 5.00 & 29.00 & 4.08 & 7.00 & 4.10 & 7.93 \\
\hline 9 & TU 94-2 & 42.50 & 74.00 & 24.90 & 3.50 & 6.50 & 36.00 & 4.06 & 7.00 & 4.20 & 8.96 \\
\hline 10 & LBG 787 & 41.00 & 72.50 & 24.41 & 3.00 & 6.00 & 33.50 & 4.02 & 7.00 & 3.85 & 8.15 \\
\hline 11 & TGBG 26 & 46.00 & 76.00 & 22.97 & 3.00 & 5.50 & 35.00 & 4.06 & 7.00 & 5.00 & 9.72 \\
\hline 12 & TGBG 344 & 40.50 & 71.50 & 21.85 & 3.00 & 3.50 & 24.50 & 4.06 & 6.50 & 4.35 & 6.31 \\
\hline 13 & TGBG 74 & 43.50 & 73.00 & 21.22 & 3.00 & 4.50 & 28.50 & 4.02 & 5.50 & 3.75 & 5.54 \\
\hline 14 & TGBG 143 & 42.50 & 74.00 & 22.50 & 3.00 & 4.00 & 24.50 & 4.08 & 5.50 & 4.50 & 5.72 \\
\hline 15 & TGBG 281 & 44.00 & 75.00 & 21.71 & 2.50 & 4.50 & 27.50 & 4.08 & 6.50 & 3.50 & 5.86 \\
\hline 16 & KUG 216 X BG 018-2 & 40.00 & 70.50 & 20.99 & 2.00 & 6.00 & 33.50 & 4.05 & 7.00 & 4.10 & 8.34 \\
\hline 17 & OPU 8831 X VBG 4-008 & 40.00 & 71.00 & 21.14 & 4.00 & 6.00 & 37.00 & 4.05 & 6.50 & 3.65 & 7.85 \\
\hline 18 & LBG 645 & 44.50 & 75.00 & 24.55 & 3.00 & 4.00 & 26.00 & 5.03 & 6.00 & 4.65 & 6.85 \\
\hline 19 & TBG 104 & 42.00 & 73.50 & 23.36 & 2.50 & 5.50 & 33.50 & 4.05 & 7.00 & 4.10 & 8.24 \\
\hline 20 & WBG 108 & 43.50 & 73.50 & 20.08 & 2.00 & 6.50 & 34.00 & 4.02 & 7.00 & 4.30 & 8.36 \\
\hline 21 & KUG 216 X PU 40 & 38.00 & 69.50 & 14.62 & 3.00 & 6.00 & 32.50 & 4.07 & 7.00 & 3.62 & 7.78 \\
\hline 22 & LBG 648 & 48.00 & 78.50 & 25.13 & 2.90 & 3.00 & 21.00 & 4.05 & 5.50 & 3.05 & 3.46 \\
\hline 23 & PU 40 & 41.50 & 71.50 & 25.13 & 3.50 & 4.50 & 29.00 & 4.03 & 7.00 & 4.80 & 8.51 \\
\hline 24 & TU 18 & 46.50 & 76.00 & 25.55 & 3.00 & 4.50 & 26.50 & 4.08 & 6.00 & 4.18 & 6.41 \\
\hline 25 & LBG 685 & 45.50 & 75.00 & 23.28 & 2.00 & 3.00 & 27.50 & 4.06 & 6.50 & 4.99 & 8.34 \\
\hline 26 & PU 31 & 40.00 & 70.00 & 18.74 & 3.00 & 5.50 & 34.00 & 4.05 & 7.00 & 3.95 & 7.92 \\
\hline 27 & TGBG 258 & 40.00 & 72.50 & 18.97 & 2.00 & 4.00 & 26.50 & 4.07 & 6.50 & 4.57 & 7.07 \\
\hline 28 & IPU 2-43 & 44.50 & 74.00 & 23.85 & 3.00 & 5.50 & 29.50 & 4.03 & 6.00 & 4.03 & 6.99 \\
\hline 29 & LBG 788 & 44.50 & 75.00 & 23.40 & 1.50 & 4.50 & 28.50 & 4.05 & 7.00 & 4.62 & 7.76 \\
\hline 30 & KUG 216 X SPS 5 & 40.00 & 71.00 & 20.19 & 3.00 & 6.00 & 28.00 & 4.08 & 6.50 & 3.54 & 6.13 \\
\hline 31 & TGBG 136 & 42.50 & 74.00 & 23.90 & 4.00 & 5.50 & 33.50 & 4.08 & 6.00 & 4.35 & 7.93 \\
\hline 32 & T 9 & 45.00 & 75.00 & 19.79 & 2.50 & 6.00 & 30.00 & 4.02 & 6.50 & 4.15 & 6.94 \\
\hline 33 & TGBG 401 & 43.00 & 73.50 & 19.59 & 2.50 & 3.50 & 24.00 & 4.03 & 6.00 & 3.22 & 4.57 \\
\hline 34 & LBG 752 & 46.50 & 76.00 & 21.60 & 3.00 & 4.50 & 27.50 & 4.04 & 6.00 & 3.99 & 6.51 \\
\hline 35 & LBG 709 & 40.00 & 70.50 & 19.95 & 3.00 & 7.00 & 36.00 & 4.09 & 7.00 & 3.86 & 8.25 \\
\hline 36 & LBG 20 & 39.00 & 71.00 & 20.55 & 2.00 & 7.00 & 38.50 & 4.04 & 7.00 & 4.12 & 9.33 \\
\hline \multicolumn{2}{|l|}{ Mean } & 43.33 & 74.04 & 21.78 & 2.76 & 5.01 & 29.81 & 4.05 & 6.44 & 4.16 & 7.20 \\
\hline \multicolumn{2}{|l|}{ C.V. } & 2.40 & 1.71 & 6.65 & 13.89 & 11.91 & 6.66 & 1.00 & 6.91 & 2.48 & 8.78 \\
\hline \multicolumn{2}{|l|}{ S.Em } & 0.73 & 0.90 & 1.02 & 0.27 & 0.42 & 1.40 & 0.03 & 0.32 & 0.07 & 0.45 \\
\hline \multicolumn{2}{|c|}{ C.D. $5 \%$} & 2.11 & 2.57 & 2.94 & 0.78 & 1.21 & 4.03 & 0.08 & 0.90 & 0.21 & 1.28 \\
\hline
\end{tabular}


Table.2 Analysis of variance for grain yield and yield component characters of $\mathbf{3 6}$ genotypes in rice fallow blackgram

[Vigna mungo (L.) Hepper]

\begin{tabular}{|c|c|c|c|c|c|c|c|c|c|c|c|}
\hline $\begin{array}{l}\text { Source of } \\
\text { Variations }\end{array}$ & df & $\begin{array}{c}\text { Days to } \\
\mathbf{5 0 \%} \\
\text { flowering }\end{array}$ & $\begin{array}{l}\text { Days to } \\
\text { maturity }\end{array}$ & $\begin{array}{c}\text { Plant } \\
\text { height } \\
(\mathbf{c m})\end{array}$ & $\begin{array}{c}\text { No.of } \\
\text { branches } \\
\text { per plant }\end{array}$ & $\begin{array}{c}\text { No. of } \\
\text { clusters } \\
\text { per plant }\end{array}$ & $\begin{array}{c}\text { No.of pods } \\
\text { per plant }\end{array}$ & $\begin{array}{c}\text { Pod } \\
\text { length } \\
\text { (cm) }\end{array}$ & $\begin{array}{c}\text { No.of seed } \\
\text { per pod }\end{array}$ & $\begin{array}{c}100 \text { Seed } \\
\text { weight }(\mathrm{g})\end{array}$ & $\begin{array}{c}\text { Grain yield } \\
\text { per plant } \\
(\mathrm{gm})\end{array}$ \\
\hline \multicolumn{12}{|c|}{ Mean sum of squares } \\
\hline Replications & 1 & 0.222 & 0.347 & 0.000 & 0.376 & 0.014 & 0.056 & 0.001 & 0.056 & 0.001 & 0.090 \\
\hline Treatments & 35 & $16.457 * *$ & $15.896 * *$ & $11.307 * *$ & $0.669 * *$ & $2.642 * *$ & $41.865 * *$ & $0.113 * *$ & $0.594 * *$ & $0.438 * *$ & $3.833 * *$ \\
\hline Error & 35 & 1.079 & 1.604 & 2.098 & 0.147 & 0.357 & 3.941 & 0.002 & 0.198 & 0.011 & 0.400 \\
\hline Total & 71 & 17.759 & 17.848 & 13.406 & 1.191 & 3.013 & 45.862 & 0.116 & 0.848 & 0.450 & 4.322 \\
\hline
\end{tabular}

Table.3 Estimates of variability, heritability and genetic advance as per cent of mean for grain yield, yield components of 36 genotypes in rice fallow blackgram [Vigna mungo (L.) Hepper]

\begin{tabular}{|c|c|c|c|c|c|c|c|c|c|}
\hline \multirow[t]{2}{*}{ S.No } & \multirow[t]{2}{*}{ Character } & \multirow[t]{2}{*}{ Mean } & \multicolumn{2}{|c|}{ Range } & \multicolumn{2}{|c|}{ Coefficient of variation (\%) } & \multirow{2}{*}{$\begin{array}{c}\text { Heritability } \\
\text { in broad } \\
\text { sense }\left(\mathbf{h}^{2}\right) \\
(\%)\end{array}$} & \multirow{2}{*}{$\begin{array}{c}\text { Genetic } \\
\text { advance } \\
(\text { GA) }(\%)\end{array}$} & \multirow{2}{*}{$\begin{array}{c}\text { Genetic } \\
\text { advance as per } \\
\text { cent of mean } \\
(\text { GAM })\end{array}$} \\
\hline & & & Min. & Max. & $\begin{array}{l}\text { Phenotypic } \\
\text { coefficient of } \\
\text { variation } \\
\text { (PCV) }\end{array}$ & $\begin{array}{l}\text { Genotypic } \\
\text { coefficient of } \\
\text { Variation } \\
\text { (GCV) }\end{array}$ & & & \\
\hline 1 & Days to $50 \%$ flowering & 43.33 & 38.00 & 48.50 & 6.83 & 6.40 & 87.70 & 5.35 & 12.34 \\
\hline 2 & Days to maturity & 74.04 & 69.50 & 80.00 & 4.00 & 3.61 & 81.70 & 4.98 & 6.72 \\
\hline 3 & Plant height $(\mathrm{cm})$ & 21.78 & 14.62 & 25.55 & 11.89 & 9.85 & 68.70 & 3.66 & 16.82 \\
\hline 4 & No.of branches per plant & 2.76 & 1.50 & 4.00 & 23.13 & 18.50 & 64.00 & 0.84 & 30.48 \\
\hline 5 & No. of clusters per plant & 5.01 & 3.00 & 7.00 & 24.42 & 21.32 & 76.20 & 1.92 & 38.34 \\
\hline 6 & No.of pods per plant & 29.81 & 21.00 & 38.50 & 16.06 & 14.61 & 82.80 & 8.16 & 27.38 \\
\hline 7 & Pod length $(\mathrm{cm})$ & 4.05 & 3.04 & 5.03 & 5.92 & 5.84 & 97.10 & 0.48 & 11.86 \\
\hline 8 & No.of seed per pod & 6.44 & 5.50 & 7.00 & 9.77 & 6.90 & 49.90 & 0.65 & 10.04 \\
\hline 9 & 100 Seed weight $(g)$ & 4.16 & 3.05 & 5.00 & 11.39 & 11.12 & 95.30 & 0.93 & 22.35 \\
\hline 10 & Grain yield per plant (gm) & 7.20 & 3.46 & 9.72 & 20.20 & 18.19 & 81.10 & 2.43 & 33.75 \\
\hline
\end{tabular}


The parameters of genetic variability such as mean, range, phenotypic coefficient of variation (PCV), genotypic coefficient of variation (GCV), heritability and genetic advance as percentage of mean (GA) were estimated for all the quantitative characters are presented in Table 2 .

The days to $50 \%$ flowering ranges from 38.00 to 48.50 days with mean of 43.33 days, days to maturity from 69.50 to 80.00 days with mean of 74.04 days, plant height varied from 14.62 to $25.55 \mathrm{~cm}$ with an mean of $21.78 \mathrm{~cm}$, number of branches per plant ranged from 1.50 to 4.00 with mean of 2.76 , number of clusters per plant from 3.00 to 7.00 with a mean of 5.01, number of pods per plant varied from 21.00 to 38.50 with mean of 29.81, number of seeds per pod ranged from 5.50 to 7.00 with mean of $6.44,100$ seed weight varied from 3.05 to $5.00 \mathrm{~g}$ with mean of 4.16 $\mathrm{g}$ and grain yield per plant varied from 3.46 to $9.72 \mathrm{~g}$ with mean of $7.20 \mathrm{~g}$, which indicates that sufficient variability is present in the genotypes for above characters.

The phenotypic coefficient of variance (PCV) was slightly higher in magnitude than genotypic coefficient of variance (GCV) for all the characters studied indicating the influence of environment on expression of these traits. Number of clusters per plant showed high PCV (24.42) and GCV (21.32). While, high PCV and moderate GCV was observed for number of branches per plant and grain yield per plant, whereas number of pods per plant and 100 seed weight exhibited moderate PCV, GCV. Plant height recorded moderate PCV and low GCV. However, low PCV, GCV were recorded for days to $50 \%$ flowering, days to maturity, pod length and number of seeds per pod (Table 3). Similar results were reported by Anu Bishnoi et al., (2017), Kondagari et al., (2017), Gowsalya et al., (2016), Monika et al., (2016) and Punia et al., (2014).
High heritability coupled with high genetic advance as per cent of mean was observed for the characters viz., number of branches per plant, number of clusters per plant, number of pods per plant, 100 seed weight and grain yield per plant, indicating that the heritability was due to additive gene effects, which may be exploited through breeding methods involving simple selection like pedigree method, mass selection, ear-to-row method etc. are to be followed to improve these traits. Whereas high heritability and moderate genetic advance as per cent of mean was recorded for the days to maturity, plant height, pod length. While, number of seeds per plant exhibited moderate heritability, genetic advance as per cent of mean, reveals that heritability was due to additive gene effects and selection may be effective. Days to maturity showed high heritability coupled with low genetic advance as per cent of mean, indicative of non-additive gene action and heritability was being exhibited due to favorable influence of environmental conditions rather than genotype and selection for this trait may not be rewarded. These results are in accordance with Anu Bishnoi et al., (2017), Monika et al., (2016), Kondagari et al., (2017), Gowsalya et al., (2016) and Punia et al., (2014).

\section{References}

Anu Bishnoi, Priyanka Gupta., Meghawal, D.R and Lal, G.M. 2017. Evaluation of genetic variability and heritability in blackgram (Vigna mungo (L.) Hepper) genotypes. Journal of Pharmacognosy and Phytochemistry, 6(4): 493-496.

Chopra V.L. 2000. Plant breeding-Theory and practice 2nd ed. Oxford and IBH Pub. Co. Pvt. Ltd, New Delhi, p.10.

Chubatemsu Ozukum and Malini Barthakur Sharma. 2017. Variability among Urdbean (Vigna Mungo L. Hepper) for Yield and Yield Components. 
International Journal of Research and Innovation in Applied Science. 2 (4): 26-28.

Gowsalya, P., Kumaresan, D., Packiaraj, D and Kannanbapu, J.R. 2016. Genetic variability and character association for biometrical traits in blackgram (Vigna mungo (L.) Hepper). Electronic Journal of Plant Breeding. 7 (2): 317-324.

Hanson, W.O. 1963. Heritability in Statistical Genetics and Plant Breeding, Hanson, W.O and Robinson, H.F. (eds.), 1982. National Academy of Science and National Research Council, Washington D. C. pp. 125-139.

Johnson, H.W., Robinson, H.F and Comstock, R.E. 1955. Estimates of genetic and environmental variability in Soybean. Agronomy Journal, 47: 314-318.

Kondagari Hemalatha., Sapna S Lal and Gabrial M Lal. 2017. Study on genetic variability and correlation in blackgram
(Vigna mungo L. Hepper). Journal of Pharmacognosy and Phytochemistry. 6 (4): 674-676

Monika Singh, Indu Swarup, M., Billore and Chaudhari, P.R. 2016. Association analysis of seed yield and its attributing traits in black gram [Vigna mungo (L.) Hepper]. Agric. Sci. Digest., 36 (2) 2016: 83-87.

Priyanka, S., Rangaiah, S and Showkath Babu, B.M. 2016. Genetic variability estimates of quantitative and qualitative traits in black gram. International Journal of Agriculture Sciences. 8 (40): 1821-1824

Punia, S.S., Gautam, N.K., Baldev Ram., Preeti Verma., Meenakshi Dheer., Jain, N.K., Koli, N.R., Rajesh Mahavar and Jat, V.S. 2014. Genetic variability and correlation studies in urdbean (Vigna mungo L.). Legume Res., 37 (6): 580584.

\section{How to cite this article:}

Hari Ram Kumar Bandi, K. Nagendra Rao, K. Vamsi Krishna and Srinivasulu, K. 2018. Variability, Heritability and Genetic Advance for Quantitative Characters in Rice Fallow Blackgram [Vigna mungo (L.) Hepper]. Int.J.Curr.Microbiol.App.Sci. 7(02): 171-176. doi: https://doi.org/10.20546/ijcmas.2018.702.022 